\title{
ECOTOXICITY AND GENOTOXICITY OF STEEL SLAGS: PRELIMINARY RESULTS
}

\author{
Laura Benassi ${ }^{1, \star}$, Carlotta Alias ${ }^{1}$, Donatella Feretti ${ }^{1,2}$, Umberto Gelatti ${ }^{1,2}$, Giovanna \\ Piovani ${ }^{1,3}$, llaria Zerbini ${ }^{1,2}$ and Sabrina Sorlini ${ }^{1,4}$ \\ ${ }^{1} B+L A B N E T$ Interdepartmental Laboratory, University of Brescia, via Branze 45, 25123 Brescia, Italy \\ ${ }_{2}^{2}$ Medical and surgical specialties, radiological sciences, and public health department, University of Brescia, viale Europa 11, 25123 \\ Brescia, Italy \\ ${ }^{3}$ Molecular and translational medicine department, University of Brescia, viale Europa 11, 25123 Brescia, Italy \\ ${ }^{4}$ Civil, environmental, architectural engineering and mathematics department, University of Brescia, via Branze 43, 25123 Brescia, Italy
}

Article Info:
Received:
16 November 2018
Revised:
19 April 2019
Accepted:
7 May 2019
Available online:
19 May 2019
Keywords:
Steel slag
Biological assay
Chemical characterization
Ecotoxicity
Genotoxicity
Steel slag reuse

\section{INTRODUCTION}

The production chain of cast iron and steel generates scrap called steel slag (SS). Two types of slags are mainly generated from the iron and steelmaking industries: basic-oxygen furnace (BOF) steel slags and electric-arc furnace (EAF) steel slag. BOF-SS are residues from the basic oxygen converter, where steel is generated by the pig iron by injecting pure oxygen. EAF-SS are generated in highpower electric arcs where high quality steel is produced by melting recycled steel scrap (Chaurand et al., 2007; Yildirim \& Prezzi, 2011). Thus, the production of SS is a result of the steel composition and of the steel production process (Yüksel, 2017).

In Europe, every year, more than 45 million tons of slag from both integral cycle furnace slabs and from electric furnaces are produced (European Slag Association and European Steel Association, 2012). The Italian production is about 6.5 million tons (Federacciai, 2012). According to the European regulations on wastes, this huge amount of material must be reduced in order to save primary resourc- es and enhancedwaste disposal minimization. As a consequence, steel slag recovery is becoming a debated problem (Piatak, Parsons, \& Seal, 2015).

Due to the mechanical and physical properties of steel, various applications can be implemented: in the construction industry, as in concrete (Rondi et al., 2016), or in road construction such as road base and asphalt mixtures (Sorlini, Sanzeni, \& Rondi, 2012). Moreover, SS can be assimilated to natural hard rocks due to the composition similar to natural aggregates. In fact, SS are characterized mainly by oxides of calcium, iron, silicon, aluminum, magnesium, and manganese (Yüksel, 2017).

The classification of slag as a by-product or waste is variable within the European member states (Euroslag, 2018). The US Environmental Protection Agency classifies iron and steelmaking slags as non-hazardous considering their ignitability, corrosivity, reactivity and toxicity ( $\mathrm{Na}$ tional Slag Association, 1980). Despite that, according to steel production process characteristics (i.e. cooling conditions, blast furnace charges and temperatures), SS can also contain potentially toxic elements, such as chromium, 
molybdenum, vanadium (Komonweeraket, Cetin, Aydilek, Benson, \& Edil, 2015; Primavera, Pontoni, Mombelli, Barella, \& Mapelli, 2016; Tossavainen et al., 2007). Moreover, the SS industry remains for a long time in the environment and therefore has a prolonged contact with environmental mixtures such as deep water and soil. It may promote the release (for example through chemical weathering) of substances potentially dangerous both for the environment and for human health (Primavera et al., 2016).

Many mutagenic/genotoxic substances can be present and accumulate in the aquatic and soil environments, and have adverse effects on biocenosis and can affect humans through drinking water (Ceretti et al., 2016; Guan et al., 2017), surface water (Ohe, Watanabe, \& Wakabayashi, 2004) and the food chain (Hamilton, Young, Bailey, \& Watts, 2018). Consequently, the diffusion of these substances in water and soil could became a public health problem (Drzeżdżon, Jacewicz, \& Chmurzyński, 2018; Rashtian, Chavkin, \& Merhi, 2019).

The increasing presence of mutagenic/genotoxic pollutants in the environment has caused concern regarding the potentially harmful effects of xenobiotics on human health. Mutagenic compounds are very dangerous pollutants, since their effects may induce damage on an individual level as well as its progeny, throughout generations. Moreover, mutagenicity is related to carcinogenicity: the evidence of mutagenic activity suggests that a substance might be carcinogenic (Bajpayee, Pandey, Parmar, \& Dhawan, 2005; Eastmond et al., 2009).

To date, Italian law requires the chemical analysis of these materials, by using short-term leaching tests in the case of re-use as supplementary cementitious materials or aggregates in concrete (Ministerial Decree n. 186, 2006). However, short-term biological tests allow an overall assessment of the analysed samples, that detect synergistic effects of complex mixture components and also predict the risks for the environment and for human health (Eastmond et al., 2009; Kirkland, Aardema, Henderson, \& Müller, 2005). In particular, ecotoxicity, mutagenicity and genotoxicity tests are useful tools to predict and prevent risks due to the presence of toxic substances in the environment. The application of these assays in different cells/organisms allows for the assessment of mutagenic hazards for the environment and for humans (Escher \& Fenner, 2011; Kirkland et al., 2005).

The aim of this study was to assess the ecotoxicity and genotoxicity of steel slags using an integrated chemical-biological approach, schematically summarized in Figure 1.

\section{MATERIALS AND METHODS}

\subsection{Materials}

Four samples of steel electric arc furnace (EAF-C) slags collected from different northern Italian steel-making plants were employed in this study. All the samples were stored from the factories in open areas and each sample collected was considered representative of the whole material storage.

Particle size ranged from 1 to $5 \mathrm{~cm}$, whereas the density ranged between 2.5 and $3.3 \mathrm{~g} / \mathrm{cm}^{3}$.

\subsection{Methods}

Chemical analysis and biological assays were performed for all the samples.

Leaching tests according to the legislation (Standard CEN EN 12457-2, 2004) were performed on grinded steel slag samples.

Leachate solutions were assayed by using ecotoxicity tests on plant and animal organisms and genotoxicity tests were done on bacteria, plant and human cells.

In particular, the toxicity was tested through the investigation on the crustacean Daphnia magna (Standard UNI EN ISO 6341, 2013) and the common onion Allium cepa (G Fiskesjö, 1995; Ma et al., 1995). Mutagenicity in bacteria was evaluated by Ames test (Maron \& Ames, 1983) and genotoxicity in plant cells was assessed by using micronuclei test in Allium cepa (Ma et al., 1995). Moreover, the micronuclei frequency in human leukocytes was studied (Fenech, 2000).

\subsubsection{Leaching tests}

Leaching tests were performed on naturally dried slag samples according to the CEN regulations (Standard CEN EN 12457-2, 2004), in order to quantify the leachable fraction of the wastes in water. Tests were performed by mixing the homogenized sample with demineralized water at a liquid to solid ratio of $10 \mathrm{l} / \mathrm{kg}$. The mixture was placed on a tightly closed rotary shaker and agitated for $24 \mathrm{~h}$, rotating at $10 \pm 2 \mathrm{rpm}$. All the steel slags were previously subjected to a crushing treatment and a sieving process in order to obtain a particle diameter below $4 \mathrm{~mm}$ and the temperature was in compliance with the Directive (about $20^{\circ} \mathrm{C}$ ). The solutions were filtered through $0.45 \mu \mathrm{m}$ filters.

Chemical analyses of the leachate solutions were performed according to the Italian legislation for the recovery of non-hazardous waste (Ministerial Decree n. 186, 2006). Nitrates, fluorides, sulphates, and chlorides were analyzed through ion chromatography (ICS 1000, Dionex). Metals were measured by means of an optical plasma spectrometer (Optima 2000 DV, PerkinElmer) and cyanides were detected by using the colorimetric method DIN 38 (Nanocolor 400D).

\subsubsection{Daphnia magna ecotoxicity test}

A preliminary short-term acute test was performed on eluates obtained from the leaching tests using Daphtoxkits $\mathrm{F}$ (Ecotox LDS). The assays were conduced according to the European Directive (Standard UNI EN ISO 6341, 2013) and by following the manufacturer's instructions.

As a first step, in order to assess the toxicity of each sample, eluates were tested without any dilution. Totally, 20 neonates of $D$. magna ( $<24$-h-old) were used for each slag leachate solution. Effects on crustacean movements or death were observed after 24 and $48 \mathrm{~h}$ of contact.

Eluates that resulted more toxic, were diluted (100\%, $50 \%, 25 \%, 12.5 \%, 6.25 \%)$ in order to assess the lowest toxic concentration. For each dilution, 20 neonates were observed after 24 and $48 \mathrm{~h}$ of incubation.

Standard freshwater was used to dilute eluates and as well as a negative control in every test. 


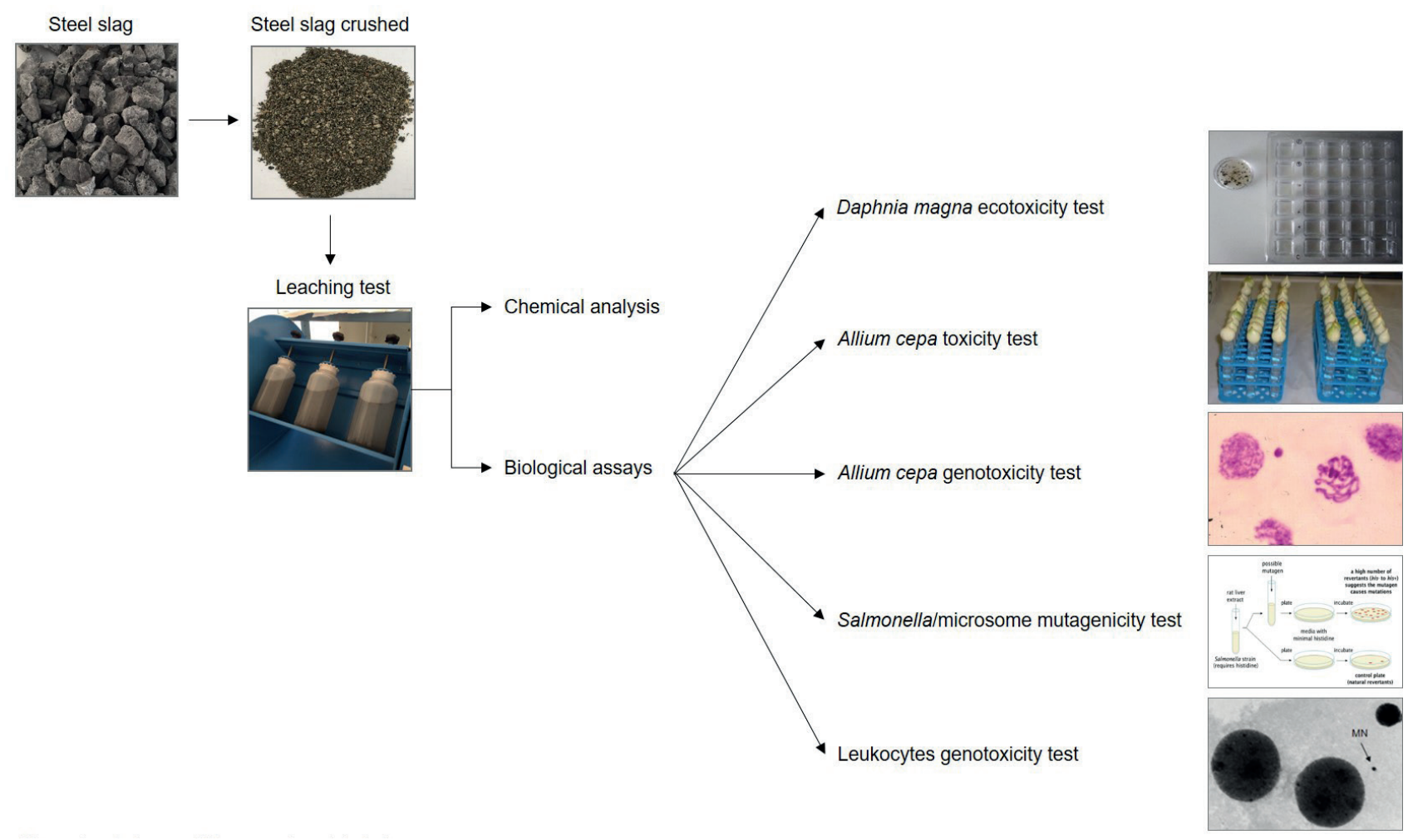

FIGURE 1: Scheme of the experimental design.

\subsubsection{Allium cepa toxicity test}

In a toxicity assay, 12 equal-sized commercial onion bulbs of A. cepa were cleaned and washed without destroying the primordial roots. They were exposed for $72 \mathrm{~h}$ in the dark to different dilutions of leachates (undiluted, 1:2, 1:10, $1: 20,1: 100,1: 200$ and 1:1000). Distilled water was used to dilute the samples and as a negative control. The roots mean length was used to calculate the EC50 value (Fiskesjö, 1985; Fiskesjö, 1995). Turgescence, consistency, colour change and root tip shape were also used as toxicity indexes.

\subsubsection{Allium cepa genotoxicity test}

The micronuclei (MN) Allium cepa test was performed by using six equal-sized young onion bulbs $(2-2.5 \mathrm{~cm}$ in diameter) per sample. After 48-h pre-germination in a saline solution, the bulbs were exposed for $24 \mathrm{~h}$ to undiluted samples based on the results obtained in the toxicity test. They were then replaced in the saline solution (Rank's solution) for $44 \mathrm{~h}$ of recovery time. The roots were cut, fixed in 1:3 acetic acid-ethanol for $24 \mathrm{~h}$ and finally stored in $70 \%$ ethanol. Staining with acetic orcein was carried out on roots. Rank's solution was used as a negative control. A positive control was performed using maleic hydrazide (10-2 $M, 6-h$ exposure) to ensure the effectiveness of the assay. Five roots of each sample were considered for the microscopic analysis ( $1,000 \mathrm{X}$ magnification): 5,000 cells ( 1,000 cells/slide) were scored for the mitotic index (MI), as a measure of the cellular division and therefore of sample toxicity; 10,000 cells (2,000 cells/slide) were scored for the $\mathrm{MN}$ frequency. All the Allium cepa experiments were performed in duplicate.

\subsubsection{Salmonella/microsome mutagenicity (Ames) test}

The leachates from steel slags were tested at increasing doses $(2.5,25,125$ and $250 \mu \mathrm{l} /$ plate) using Salmonella typhimurium TA98 and TA100 strains, with and without in vitro metabolic activation $( \pm S 9)$ to detect direct and indirect mutagenic compounds. The experimental procedure was the standard plate incorporation method (Maron \& Ames, 1983). The Salmonella TA98 strain detects frame-shift mutagens and the TA100 strain responds to base-pair substitution. Positive controls were 2-nitrofluorene $(10 \mu \mathrm{g} /$ plate; more than 1,000 revertents/plate) and sodium azide (10 $\mu \mathrm{g} /$ plate; more than 1,000 revertents/plate) for the TA98 without S9 and the TA100 without S9, respectively, and 2-aminofluorene (20 $\mu \mathrm{g} /$ plate; more than 1,000 revertents/ plate) for both strains with S9. The distilled water was a negative control. The results were espressed as a mutagenicity ratio (MR) obtained by dividing the revertants of each sample (computed by means of three replicates) by the spontaneous mutation rate (negative control). The test results were considered positive if two consecutive dose levels or the highest non-toxic dose level produced a response at least twice that of the negative control and at least two consecutive doses showed a dose-response relationship (APHA, 2012; Mortelmans \& Zeiger, 2000).

\subsubsection{Leukocytes genotoxicity test}

MN frequency is a biomarker of early genetic effects which is often used in human biomonitoring studies. The $\mathrm{MN}$ frequency analysis was obtained with the cytokinesis-block micronucleus (CBMN) assay. The CBMN assay was performed according to the standard protocol de- 
scribed by Fenech (Fenech, 2000). Briefly, whole blood was collected from a healthy donor and maintained at $37^{\circ} \mathrm{C}$ in darkness. Cultures were set up by adding $0.2 \mathrm{ml}$ of whole blood to $2 \mathrm{ml}$ of RPMl-1640 medium (Gibco), supplemented with $10 \%$ fetal bovine serum (FBS), $1 \%$ phytohaemagglutinin (PHA), 1\% glutamine and antibiotics (penicillin: 10,000 $\mathrm{U} / \mathrm{ml}$; streptomycin: 10,000 g/ml (Biochrom)). After $24 \mathrm{~h}$ of PHA stimulation, leaching solutions were added and after $24 \mathrm{~h}$ of exposure, cytochalasin B (Sigma, Steinheim, Germany) was added at a final concentration of $4.5 \mu \mathrm{g} /$ $\mathrm{ml}$. Cells were harvested at the $72^{\text {th }}$ hour after hypotonic treatment $(0.5 \% \mathrm{KCl}, 7 \mathrm{~min})$ and fixed with the Carnoy's fixative 3:1 (methanol:acetic acid) with multiple changes till a clear pellet was obtained. Slides were prepared by the airdry method and stained with 5\% Giemsa for 20 min. With the CBMN assay, the frequency of $\mathrm{MN}$ in binucleated cells was measured. In this preliminary study, only the results obtained from the single dose of $2.5 \mu$ l of leachates are reported.

\section{RESULTS AND DISCUSSION}

The steel slag composition is reported in Table 1 , in terms of leachable fraction derived from chemical analysis. All the four steel slag samples were characterized by similar concentration of the analyzed compounds. $\mathrm{pH}$ values indicated high alkalinity, as seen in the literature (Astrup, Mosbaek, \& Christensen, 2006; Gomes et al., 2017). Sample A evidenced higher contents of nitrate, chloride, barium and vanadium with respect to other samples whereas sulphate concentrations were higher in sample B. Vanadium is a common critical element in steel slag, because it is a transition metal typically used in the metal alloy industries and can generate carcinogenic effects in humans (Gomes et al., 2017; IARC, 2006). Sulphate concentrations may affect the possible reuse of this waste in the building field from a mechanical point of view. Indeed, cracks and expansion problems can appear in concrete under sulphate attack (Ali et al., 2011). Another potentially toxic element commonly present in the steel slag leachate solution is chromium (Sas, Głuchowski, Radziemska, Dzięcioł, \& Szymański, 2015). Sample C presents the highest concentration of this element $(29 \mu \mathrm{g} / \mathrm{l})$, although it is significantly below the limit value of $50 \mu \mathrm{g} / \mathrm{l}$. Overall, the chemical analysis of all eluates obtained in our study were within the reference values required by the Italian decree for the recovery of waste (Ministerial Decree n. 186, 2006).

In this study, solutions obtained from leaching tests of four steel slags were assayed by using ecotoxicity tests on plant and animal organisms and genotoxicity tests on bacteria, plant and human cells.

Toxicity tests on steel slag leaching solutions through $D$. magna and $A$. cepa were performed.

Data obtained from the Daphnia magna toxicity test are summarized in Table 2 . The validity criteria of the assay was respected, where a percentage of immobilization of the controls below $10 \%$.

Preliminary results on crustacean immobilization using undiluted SS leaching solutions revealed differences among the samples: neither after 24 hours nor after 48 hours of observation, did samples A and B show toxic effects. Sample $C$ resulted toxic with a mortality rate of $100 \%$ after 24 hours. Sample D showed an increase of immobilization from 30\% (after 24 hours) to 75\% (after 48 hours). According to the European Standard (UNI EN ISO 6341, 2013), a more detailed test was carried out on samples C and D using different dilutions. Sample $C$ caused a high level of immobilization ( $90 \%$ after 48 hours) even at the lowest concentration (6.25\%), while sample D showed a clear dose-response relationship between the sample concentration and Daphnia neonate immobilization. Immobilization by samples $C$ and $D$ could have been due to high $\mathrm{pH}$ values. As indicated by the European Standard UNI EN ISO 6341, tests should be performed without $\mathrm{pH}$ modification because "an adjustment of $\mathrm{pH}$ can alter the nature of the sample" (UNI EN ISO 6341, 2013). However, if toxic effects are observed and the $\mathrm{pH}$ of the tested solution is outside the range of the organism survival, experiments can be performed by modifying the $\mathrm{pH}$ with no more than $5 \%$ of chemicals (UNI EN ISO 6341, 2013). Further investigations are planned to clarify this point.

The Allium cepa toxicity test revealed the absence of toxicity in Allium cepa. In fact, all samples (both undiluted and diluted) did not influence the length of the roots. Moreover, no other sign of toxicity, as turgescence, consistency, color change and root tip shape, was observed in macroscopic parameters. Due to the absence of toxicity in roots, the undiluted samples were assayed in the Allium cepa genotoxicity test.

The results of Allium cepa genotoxicity test are reported in Table 3. The mitotic index (MI) showed that the eluates did not negatively influence cell division: MI values of samples are very similar to the negative control value and this allowed to consider the data of the micronuclei. No sample induced a statistically significant increase in the frequency of $\mathrm{MN}$, thus highlighting the absence of genotoxicity in these cells.

Results of the Ames test by using Salmonella typhimurium TA98 and TA100 strains expressed as a mutagenicity ratio (MR) are reported in Table 4 . No mutagenic activity was found for the SS eluates sample at all doses tested.

Table 5 reports the results of the preliminary micronucleus (MN) test performed at the dose of $2.5 \mu \mathrm{l}$ of SS leachates. Data are expressed as the frequency of mononucleated (MONO), binucleated (BN), multinucleated (POLY) and the number of $M N$ in each binucleated cell (MN/BN). Since the MN/BN was below 3, which is the cut-off number for the genotoxicity identification, no genotoxicity effects were detected at the tested dose.

The limited number of samples did not allow the authors to perform a detailed statistical analysis.

To date little is known about the toxicity of substances potentially released by steel slags (Suh et al., 2014; Radić et al., 2013), moreover there are no studies about genotoxicity of these materials.

For these reasons, we focused on the integration of chemical analysis, requested and codified by the legislation (Ministerial Decree n. 186, 2006), with biological assays to describe in detail the effects of steel slags on the environment and in humans. This combined procedure rep- 
TABLE 1: Chemical characterization of leachates from steel slag. n.d: not detected.

\begin{tabular}{|c|c|c|c|c|c|c|}
\hline \multicolumn{7}{|c|}{ Sample } \\
\hline Parameters & M.U. & A & B & c & D & $\begin{array}{l}\text { Limit value } \\
\text { DM 186/2006 }\end{array}$ \\
\hline \multicolumn{7}{|l|}{ Concentration } \\
\hline Nitrate & $\mathrm{mg} / \mathrm{l}$ & 5.0 & 1.1 & 1.7 & 1.9 & 50 \\
\hline Fluoride & $\mathrm{mg} / \mathrm{l}$ & 0.21 & 0.26 & 0.31 & 0.64 & 1.5 \\
\hline Sulphate & $\mathrm{mg} / \mathrm{l}$ & 1.0 & 26.2 & 7.0 & 9.7 & 250 \\
\hline Chloride & $\mathrm{mg} / \mathrm{l}$ & 9.2 & 5.7 & 4.8 & 5.8 & 100 \\
\hline Cyanide & $\mathrm{mg} / \mathrm{l}$ & $<5$ & $<5$ & $<5$ & $<5$ & 50 \\
\hline Barium & $\mathrm{mg} / \mathrm{l}$ & 0.27 & 0.16 & 0.17 & 0.23 & 1 \\
\hline Copper & $\mathrm{mg} / \mathrm{l}$ & $<0.01$ & $<0.01$ & $<0.01$ & $<0.01$ & 0.05 \\
\hline Zinc & $\mathrm{mg} / \mathrm{l}$ & $<0.01$ & $<0.01$ & $<0.01$ & $<0.01$ & 3 \\
\hline Beryllium & $\mu \mathrm{g} / \mathrm{l}$ & $<10$ & $<10$ & $<10$ & $<10$ & 10 \\
\hline Cobalt & $\mu \mathrm{g} / \mathrm{l}$ & $<10$ & $<10$ & $<10$ & $<10$ & 250 \\
\hline Nichel & $\mu \mathrm{g} / \mathrm{l}$ & $<10$ & $<10$ & $<10$ & $<10$ & 10 \\
\hline Vanadium & $\mu \mathrm{g} / \mathrm{l}$ & 228 & 157 & 68 & 189 & 250 \\
\hline Arsenic & $\mu \mathrm{g} / \mathrm{l}$ & $<5$ & $<5$ & $<5$ & $<5$ & 50 \\
\hline Cadmium & $\mu \mathrm{g} / \mathrm{l}$ & $<4$ & $<4$ & $<4$ & $<4$ & 5 \\
\hline Total Chromium & $\mu \mathrm{g} / \mathrm{l}$ & $<10$ & $<10$ & 29 & 12 & 50 \\
\hline Lead & $\mu \mathrm{g} / \mathrm{l}$ & $<10$ & $<10$ & $<10$ & $<10$ & 50 \\
\hline Selenium & $\mu \mathrm{g} / \mathrm{l}$ & $<10$ & $<10$ & $<10$ & $<10$ & 10 \\
\hline Mercury & $\mu \mathrm{g} / \mathrm{l}$ & $<1$ & $<1$ & $<1$ & $<1$ & 1 \\
\hline Asbestos & $\mathrm{mg} / \mathrm{l}$ & n.d. & n.d. & n.d. & n.d. & 30 \\
\hline COD & $\mathrm{mg} / \mathrm{l}$ & $<15$ & $<15$ & $<15$ & $<15$ & 30 \\
\hline $\mathrm{pH}$ & - & 10.2 & 10.5 & 11.3 & 10.9 & $5.5-12$ \\
\hline
\end{tabular}

TABLE 2: Results of Daphnia magna toxicity test on undiluted solution (samples $A$ and $B$ ) and on undiluted and diluted samples (samples $\mathrm{C}$ and $\mathrm{D}$ ).

\begin{tabular}{|c|c|c|c|}
\hline \multirow[b]{2}{*}{ Sample } & \multirow[b]{2}{*}{ Concentration \% } & \multicolumn{2}{|c|}{ Immobilization \% } \\
\hline & & $24 \mathrm{~h}$ & $48 \mathrm{~h}$ \\
\hline \multirow[t]{2}{*}{ A } & 100 & 0 & 5 \\
\hline & control & 0 & 0 \\
\hline \multirow[t]{2}{*}{ B } & 100 & 0 & 0 \\
\hline & control & 0 & 0 \\
\hline \multirow[t]{6}{*}{ C } & 100 & 95 & 100 \\
\hline & 50 & 100 & 100 \\
\hline & 25 & 100 & 100 \\
\hline & 12.5 & 90 & 100 \\
\hline & 6.25 & 10 & 90 \\
\hline & control & 0 & 0 \\
\hline \multirow[t]{6}{*}{ D } & 100 & 30 & 75 \\
\hline & 50 & 5 & 20 \\
\hline & 25 & 10 & 10 \\
\hline & 12.5 & 0 & 5 \\
\hline & 6.25 & 0 & 0 \\
\hline & control & 0 & 0 \\
\hline
\end{tabular}

Control solution: standard freshwater
TABLE 3: Results of Allium cepa genotoxicity test: mitotic index (MI) and frequency of micronuclei (MN) in Allium cepa roots.

\begin{tabular}{l|c|c}
\multicolumn{1}{c}{ Sample } & $\begin{array}{c}\text { MI } \\
(\%)\end{array}$ & $\begin{array}{c}\text { MN } \\
\text { (mean } \pm \text { SD) }\end{array}$ \\
\hline A & 12.7 & $1.0 \pm 2.2$ \\
\hline B & 12.7 & $1.4 \pm 0.9$ \\
\hline C & 11.8 & $2.8 \pm 3.7$ \\
\hline D & 13.0 & $2.0 \pm 1.7$ \\
\hline Negative control & 11.4 & $0.6 \pm 1.3$ \\
\hline Positive control & 8.1 & $19.3 \pm 14.2$ \\
\hline
\end{tabular}

resents an innovative methodological approach that could be improved in the standard procedure for the analysis of SS slag destined for re-use.

In conclusion, chemical composition of all the leaching solutions assayed respects the limits of the Italian legislation on waste recovery. The preliminary results of the Daphnia magna test on the leaching solutions of these wastes indicate in general a low inhibition of mobility in the majority of the samples. However, since one sample resulted very toxic for these crustacea, more detailed experiments are in course regarding the effect of different $\mathrm{pH}$ and dilution factors of the solutions.

All samples showed the absence of toxicity (length of roots) and genotoxicity ( $\mathrm{MN}$ frequency) in the root cells in 
TABLE 4: Results of Ames test using Salmonella typhimurium TA98 and TA100 strains, expressed as mutagenicity ratio (RM).

\begin{tabular}{|c|c|c|c|c|c|}
\hline Sample & $\begin{array}{c}\text { Dose } \\
\text { ( } \mu \mathrm{l} / \text { plate) }\end{array}$ & $\begin{array}{c}\text { TA98 - S9 } \\
\text { RM }\end{array}$ & $\begin{array}{c}\text { TA98 + S9 } \\
\text { RM }\end{array}$ & $\begin{array}{c}\text { TA100 - S9 } \\
\text { RM }\end{array}$ & $\begin{array}{c}\text { TA100 + S9 } \\
\text { RM }\end{array}$ \\
\hline \multirow[t]{4}{*}{ A } & 250 & 0.94 & 1.22 & 0.75 & 0.65 \\
\hline & 125 & 1.34 & 1.16 & 0.61 & 0.76 \\
\hline & 25 & 0.90 & 1.22 & 0.52 & 0.69 \\
\hline & 2.5 & 1.16 & 1.30 & 0.66 & 0.82 \\
\hline \multirow[t]{4}{*}{ B } & 250 & 0.71 & 0.84 & 0.88 & 1.07 \\
\hline & 125 & 1.19 & 0.90 & 1.02 & 1.07 \\
\hline & 25 & 1.21 & 1.13 & 0.90 & 0.90 \\
\hline & 2.5 & 0.81 & 1.18 & 0.83 & 1.00 \\
\hline \multirow[t]{4}{*}{ C } & 250 & 0.77 & 1.09 & 0.88 & 0.98 \\
\hline & 125 & 1.13 & 1.43 & 0.94 & 0.77 \\
\hline & 25 & 0.84 & 1.48 & 0.98 & 0.86 \\
\hline & 2.5 & 1.06 & 1.24 & 0.90 & 0.85 \\
\hline \multirow[t]{4}{*}{ D } & 250 & 0.69 & 1.36 & 0.69 & 0.91 \\
\hline & 125 & 0.88 & 1.39 & 0.87 & 0.97 \\
\hline & 25 & 1.17 & 1.09 & 0.86 & 0.93 \\
\hline & 2.5 & 0.73 & 1.16 & 0.97 & 0.96 \\
\hline
\end{tabular}

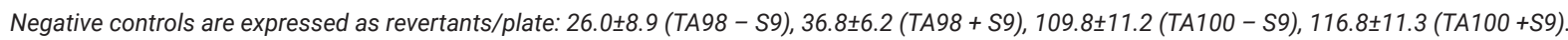

TABLE 5: Micronucleus test in human cells: frequency of mononucleated (MONO), binucleated (BN), multinucleated (POLY) and the number of binucleated cells with micronuclei (MN/BN).

\begin{tabular}{|c|c|c|c|c|c|c|}
\hline Sample & Dose $(\mu \mathrm{l})$ & MONO & $\mathrm{BN}$ & POLY & Total cells & MN/BN \\
\hline Control & 2.5 & 725 & 165 & 110 & 1000 & 0 \\
\hline $\mathrm{Ctrl}+\mathrm{H}_{2} \mathrm{O}$ & 2.5 & 747 & 157 & 96 & 1000 & 1 \\
\hline A & 2.5 & 776 & 114 & 110 & 1000 & 3 \\
\hline B & 2.5 & 779 & 124 & 107 & 1000 & 2 \\
\hline C & 2.5 & 770 & 128 & 102 & 1000 & 3 \\
\hline $\mathrm{D}$ & 2.5 & 769 & 121 & 110 & 1000 & 1 \\
\hline
\end{tabular}

the Allium cepa test. In line with our results, a pot experiment on growth of maize demonstrated the usefulness of EAF steel slag as a non-phytotoxic nutrient supplier (Radic et al., 2013). Moreover, no mutagenic activity was observed in bacteria with the Ames test.

Regarding the biological assay on human cells, the presence of $\mathrm{MN}$ in binucleated cells within the limits (normal range $0-3 ;>3$ genotoxicity index), demonstrated that the cultured cells did not undergo genotoxic damage from the tested leachates. Further concentrations will be evaluated. Also Suh and coworkers characterized the potential toxicity of EAF slag using an in vitro human dermal model, discovering that EAF slags were not a dermal sensitizer (Suh et al., 2014).

\section{CONCLUSIONS}

Our investigation is still preliminary, but results of genotoxicity tests indicate a low toxicity of steel slags. Naturally, it is necessary to further investigate the genotoxicity in other types of cells, especially mammalian cells. Due to the very low number of steel slag samples, a whole battery of biological tests will be repeated on a larger number of samples.
The reuse of steel slag wastes will undoubtedly have an environmental and economic advantages. Knowledge about the potential toxic element release and especially the effect it has on the human and environmental health, is therefore fundamental in finding new applications for steel slags.

\section{AKNOWLED GEMENTS}

The authors would like to thank the PBR s.r.l., Maclodio - Brescia, Italy, for the chemical characterization of the slag samples.

This work was supported by the "Health and Wealth Strategic Programme" of the University of Brescia.

\section{REFERENCES}

Ali, K. S., Norishahaini, M. I., \& Mohd Ridzuan, A. R. (2011). Performance of concrete containing steel slag exposed to sulphate environment: A comparison of steel slag and natural aggregate use. In 2011 IEEE Symposium on Business, Engineering and Industrial Applications (ISBEIA) (pp. 570-575). IEEE. https://doi.org/10.1109/ ISBEIA.2011.6088883

APHA. (2012). Standard Methods for the Examination of Water and Wastewater. 22nd ed. Washington. 
Astrup, T., Mosbaek, H., \& Christensen, T. H. (2006). Assessment of long-term leaching from waste incineration air-pollution-control residues. Waste Management (New York, N.Y.), 26(8), 803-814. https://doi.org/10.1016/j.wasman.2005.12.008

Bajpayee, M., Pandey, A. K., Parmar, D., \& Dhawan, A. (2005). Current Status of Short-Term Tests for Evaluation of Genotoxicity, Mutagenicity, and Carcinogenicity of Environmental Chemicals and NCEs. Toxicology Mechanisms and Methods, 15(3), 155-180. https:// doi.org/10.1080/15376520590945667

Ceretti, E., Moretti, M., Zerbini, I., Villarini, M., Zani, C., Monarca, S., \& Feretti, D. (2016). Occurrence and control of genotoxins in drinking water: A monitoring proposal. Journal of Public Health Research, 5(3), 116-121. https://doi.org/10.4081/jphr.2016.769

Chaurand, P., Rose, J., Briois, V., Olivi, L., Hazemann, J.-L., Proux, O., .. Bottero, J.-Y. (2007). Environmental impacts of steel slag reused in road construction: a crystallographic and molecular (XANES) approach. Journal of Hazardous Materials, 139(3), 537-542. https:// doi.org/10.1016/j.jhazmat.2006.02.060

Drzeżdżon, J., Jacewicz, D., \& Chmurzyński, L. (2018). The impact of environmental contamination on the generation of reactive oxygen and nitrogen species - Consequences for plants and humans. Environment International, 119(April), 133-151. https://doi. org/10.1016/j.envint.2018.06.019

Eastmond, D. A., Hartwig, A., Anderson, D., Anwar, W. A., Cimino, M. C., Dobrev, I., ... Vickers, C. (2009). Mutagenicity testing for chemical risk assessment: update of the WHO/IPCS Harmonized Scheme. Mutagenesis, 24(4), 341-349. https://doi.org/10.1093/mutage/gep014

Escher, B. I., \& Fenner, K. (2011). Recent Advances in Environmental Risk Assessment of Transformation Products. Environmental Science \& Technology, 45(9), 3835-3847. https://doi.org/10.1021/ es1030799

Euroslag (2018). http://www.euroslag.com/status-of-slag/legislation/ (accessed 9.14.18)

Federacciai. (2012). La valorizzazione degli aggregati di origine siderurgica; La scoria siderurgica: da problema a risorsa.

Fenech, M. (2000). The in vitro micronucleus technique. Mutation Research, 455(1-2), 81-95.

Fiskesjö, G. (1985). The Allium test as a standard in environmental monitoring. Hereditas, 102(1), 99-112. https://doi. org/10.1111/j.1601-5223.1985.tb00471.x

Fiskesjö, G. (1995). Allium test. Methods in Molecular Biology (Clifton, N.J.), 43, 119-127. https://doi.org/10.1385/0-89603-282-5:119

Gomes, H. I., Jones, A., Rogerson, M., Greenway, G. M., Lisbona, D. F., Burke, I. T., \& Mayes, W. M. (2017). Removal and recovery of vanadium from alkaline steel slag leachates with anion exchange resins. Journal of Environmental Management, 187, 384-392. https://doi.org/10.1016/J.JENVMAN.2016.10.063

Guan, Y., Wang, X., Wong, M., Sun, G., An, T., Guo, J., \& Zhang, G. (2017). Evaluation of Genotoxic and Mutagenic Activity of Organic Extracts from Drinking Water Sources. Plos One, 12(1), e0170454. https://doi.org/10.1371/journal.pone.0170454

Hamilton, E. M., Young, S. D., Bailey, E. H., \& Watts, M. J. (2018). Chromium speciation in foodstuffs: A review. Food Chemistry, 250(August 2017), 105-112. https://doi.org/10.1016/j.foodchem.2018.01.016

IARC. (2006). IARC Monographs on the evaluation of carcinogenic risks to humans: Cobalt in hard metals and cobalt sulfate, gallium arsenide, indium phosphide and

Kirkland, D., Aardema, M., Henderson, L., \& Müller, L. (2005). Evaluation of the ability of a battery of three in vitro genotoxicity tests to discriminate rodent carcinogens and non-carcinogens. Mutation Research/Genetic Toxicology and Environmental Mutagenesis, 584(12), 1-256. https://doi.org/10.1016/j.mrgentox.2005.02.004

Komonweeraket, K., Cetin, B., Aydilek, A. H., Benson, C. H., \& Edil, T. B. (2015). Effects of $\mathrm{pH}$ on the leaching mechanisms of elements from fly ash mixed soils. Fuel, 140, 788-802. https://doi. org/10.1016/j.fuel.2014.09.068
Ma, T. H., Xu, Z., Xu, C., McConnell, H., Rabago, E. V, Arreola, G. A., \& Zhang, H. (1995). The improved Allium/Vicia root tip micronucleus assay for clastogenicity of environmental pollutants. Mutation Research, 334(2), 185-195.

Maron, D. M., \& Ames, B. N. (1983). Revised methods for the Salmonella mutagenicity test. Mutation Research, 113(3-4), 173-215.

Ministerial Decree n. 186. Ministerial Decree "Regolamento recante modifiche al decreto ministeriale 5 febbraio 1998 «Individuazione dei rifiuti non pericolosi sottoposti alle procedure semplificate di recupero, ai sensi degli articoli 31 e 33 del decreto legislativo 5 febbraio 199 (2006)

Mortelmans, K., \& Zeiger, E. (2000). The Ames Salmonella/microsome mutagenicity assay. Mutation Research, 455(1-2), 29-60.

National Slag Association. (1980). Iron and steel slag- non-hazards.

Ohe, T., Watanabe, T., \& Wakabayashi, K. (2004). Mutagens in surface waters: A review. Mutation Research - Reviews in Mutation Research, 567(2-3 SPEC. ISS.), 109-149. https://doi.org/10.1016/j. mrrev.2004.08.003

Piatak, N. M., Parsons, M. B., \& Seal, R. R. (2015). Characteristics and environmental aspects of slag: A review. Applied Geochemistry, 57, 236-266. https://doi.org/10.1016/j.apgeochem.2014.04.009

Position Paper on theStatus of Ferrous Slag complying with the Waste Framework Directive (Articles $5 / 6$ ) and the REACH Regulation The European Slag Association The European Steel Association. (2012).

Primavera, A., Pontoni, L., Mombelli, D., Barella, S., \& Mapelli, C. (2016). EAF Slag Treatment for Inert Materials' Production. Journal of Sustainable Metallurgy, 2(1), 3-12. https://doi.org/10.1007/s40831015-0028-2

Rashtian, J., Chavkin, D. E., \& Merhi, Z. (2019). Water and soil pollution as determinant of water and food quality/contamination and its impact on female fertility. Reproductive Biology and Endocrinology, 17(1), 1-13. https://doi.org/10.1186/s12958-018-0448-5

Rondi, L., Bregoli, G., Sorlini, S., Cominoli, L., Collivignarelli, C., \& Plizzari, G. (2016). Concrete with EAF steel slag as aggregate: A comprehensive technical and environmental characterisation. https://doi. org/10.1016/j.compositesb.2015.12.022

Sas, W., Głuchowski, A., Radziemska, M., Dzięcioł, J., \& Szymański, A (2015). Environmental and Geotechnical Assessment of the Steel Slags as a Material for Road Structure. Materials (Basel, Switzerland), 8(8), 4857-4875. https://doi.org/10.3390/ma8084857

Singh, N. P., McCoy, M. T., Tice, R. R., \& Schneider, E. L. (1988). A simple technique for quantitation of low levels of DNA damage in individual cells. Experimental Cell Research, 175(1), 184-191.

Sorlini, S., Sanzeni, A., \& Rondi, L. (2012). Reuse of steel slag in bituminous paving mixtures. Journal of Hazardous Materials, 209-210, 84-91. https://doi.org/10.1016/j.jhazmat.2011.12.066

Standard CEN EN 12457-2. (2004). Characterisation of waste leaching compliance test for leaching of granular waste materials and sludges part 2: One stage batch test at a liquid to solid ratio of $10 \mathrm{~L} / \mathrm{kg}$ for materials with particle size below $4 \mathrm{~mm}$. European Committee for Standardization.

Tice, R. R., Agurell, E., Anderson, D., Burlinson, B., Hartmann, A., Kobayashi, H., ... Sasaki, Y. F. (2000). Single cell gel/comet assay: guidelines for in vitro and in vivo genetic toxicology testing. Environmental and Molecular Mutagenesis, 35(3), 206-221.

Tossavainen, M., Engstrom, F., Yang, Q., Menad, N., Lidstrom Larsson, M., \& Bjorkman, B. (2007). Characteristics of steel slag under different cooling conditions. Waste Management, 27(10), 13351344. https://doi.org/10.1016/J.WASMAN.2006.08.002

UNI EN ISO 6341. (2013). Determination of the inhibition of the mobility of Daphnia magna Straus (Cladocera, Crustacea).

Yildirim, I. Z., \& Prezzi, M. (2011). Chemical, Mineralogical, and Morphological Properties of Steel Slag. Advances in Civil Engineering, 2011, 1-13. https://doi.org/10.1155/2011/463638

Yüksel, í. (2017). A review of steel slag usage in construction industry for sustainable development. Environment, Development and Sustainability, 19(2), 369-384. https://doi.org/10.1007/s10668016-9759-x 